\title{
HYALASE (HYALUNONIIASSE) INJECTION FOR LEPROMATOUS NERVE REACTIONS
}

A. S. Garrett, M.B., M.R.C.S., L.R.C.P. Area Superintendent, Onitsha Province, E. Nigeria

While visiting Oji River early in 1955, Dr. Gordon Currie suggested the use of hyalase to diminish the pain and disability of those with severe nerve reactions. He, himself, was on the move and has not had opportunity to test his idea. I have had that opportunity and with his permission I write about these cases.

At first I decided to choose my cases among those with severe reactions in two nerves, using the worst nerve to try the treatment and keeping the other for comparison. I also decided to use nerves which had had severe and frequently repeated reactions. Some nerve reactions are of short duration and repeated only once or twice so that success in these cases would not be significant. My first resolution was only kept partially, as the worse nerve almost invariably became the better nerve and with such intractable pain I could not leave the patient without effective treatment of the other nerve for weeks on end. Several of these patients had previously had procaine injections, nerve-stripping and plenty of Tabs. Codeine Co.

Hyalase was first given by dissolving one ampoule $(3 \mathrm{mg}$.) in $20 \mathrm{ml}$. of sterile water. This was injected into the affected nerves. In some cases it was so painful that I decided to dissolve it in 2 per cent procaine instead. This, though still rather painful at first, as any intra-neural injection would be, was satisfactory. About 5 to $6 \mathrm{ml}$. were injected into each affected nerve, though account was taken of the size and length of nerve affected. Injections were given at weekly intervals and a course of five injections per nerve was used as the standard. Both these decisions were empirical.

All injections were attempted intraneurally, starting from the upper end of the nerve. Some of the worst cases, however, had such hard nerves that this was impossible. A perineural injection was then given.

When several nerves were injected at the same time, one ampoule of hyalase was dissolved per 20 to $30 \mathrm{ml}$. of solvent, e.g. when $75 \mathrm{ml}$. were needed, 3 ampoules were used.

Ahbreviations.-L.U. and R.U.: Left and Right Ulner nerve. L.E.P. and R.E.P.: Left and Right External Popliteal nerve. L.M.C. and R.M.C.: and Right Musculocutaneous branch of E.P. 


\section{Case Reports}

N.N. Female. Age. 26. Z/5121. Leprona to years standing. May 1951, started dapsone treatment. September 1953, first negative smear. Started nerve reactions shortly before smears became negative. Progressive increase in pain, but only slight paralysis and anaesthesia. May 1954, R. and L. U. nerves stripped, sheath very adherent to nerve and surrounding tissues. July 1954, continued nerve reactions in ulnars. January 1955, R. Radial and L. Median at wrist stripped. These were fairly successful, but ulnars continued painful, and R. and L.M.C. started reaction. July 1955, L.U. very painful, R. U. less so. Hyalase started in L.U. and dramatic improvement. R.U. started next week and R. and I..M.C. started next month. R. Radial started 6 weeks later.. She had Io injections in I..U., 5 in R.U., 2 in R.M.C. and R Radial, and 4 in L.M.C. All except L.M.C. became painless. The latter was stripped and found to have a very thicik sheath.

November 1955, she has never, since nerve reactions started, had continued freedom from pain for three months until now. She is brighter and happier. The nerves feel surall and not so hard. She says she can feel better with her hands.

E.E. Male. Age 27. Z/2238. 1950, severe nodular leproma with large U.S and E.P.S., started dapsone. July, 1952, first severe nerve reaction. December 1954 , first negative smear. Had frequent nerve and lepra reactions starting from 1952 onwards. June 1955, L.U. injected with hyalase with success (6 injections), 6 weeks later R.U. had 5 injections. October 1955, he had mild recurrence in L.U. and given 3 more injections. November 1955, greatly improved. Nerves smaller and not very hard and he is much brighter in himself.

C.O. Male. Age 35. Z/2446. June 1954, admitted with severe nodular leproma, with large U.s and E.P.S. July 1955, much better but R.U. very painful and very large. Hyalase given 5 times. Pain all gone. November 1955, no further trouble.

E.A. Male. Age 18. Z/2425. April 1954, admitted with very severe crippling. He had slightly active minor tuberculoid leprosy. His hands have felt very cold, in addition to being paralysed and rather painful in the ulnar area. September 1955, L.U. and R.U., 5 injections of hyalase given. November 1955, says his hands are a bit stronger and he feels better and has no pain. The only obvious objective sign is that his hands are no longer cold as they have been for the past year or more.

There are 24 such cases and nearly all show the same uniform improvement:-

(a) lessening of pain,

(b) reduction in size of nerves,

(c) claims of increased strength and ability to feel heat and touch better.

I wish, however, to report all those in which there has been failure of any kind, though in most of these success has been at least partial.

N.N. Female. Age 26. Z/5121. As reported above, the L.M.C. did not improve until a nerve stripping had been done. All other nerves improved dramatically.

O.J. Male. Age 38. Z/2009. Leproma over I3 years. 1950, started dapsone. April 1955, first negative smear. Nerve reactions started about same time in R. and L.U. July 1955, R.U. injected II times. L.U. 5 times. 21st November, 1955 ( I week after last injection in R.U.), both nerves much smaller and free from pain and tenderness. Patient says anaesthesia is less and hands are stronger. But R.U. has paraesthesia near wrist, which was not present before. 
M.O. Female. Age 40. Z/1797. September 1950, nodula leproma, thighs and buttocks ulcerated. 1954, nerve reactions started. September 1955, I.U., R.U. and R.M.C. injected 5 times each. November 1955, all better, but R.U. has had a mild reaction since then.

V.D. Male. Age 35. $\mathrm{Z} / 1740$. His nerve reactions subsided, but the hyalase gave him generalised pain and weakness for a day after each injection. He continued his course at his own request because of improvement in the nerves. November 1955, they have remained without pain for 5 months.

O.E. Male. Age 27. Z/2008. August 1951, severe infiltrated leproma U.s and E.P.s. +. 1954, started ulnar reactions. April 1955, had one hyalase injection in each ulnar. September 1955, returned for two more, but owing to pain did not bother to come aagin.

A.N. Male. Age 22. Z/2256. January 1953, extensive borderline macules with enlarged U.s and E.P.s. January 1955, reported tender L.U. just behind epicondyle. August 1955, 5 injections of hyalase. September 1955, pain reported improved. November 1955, thinks there is no real change for better or worse since the start of hyalase.

\section{Conclusion}

Though this is only a short trial, I am of the opinion that this treatment holds out better hope for those suffering from nerve reactions than any treatment so far used. Of course, it is not used in those cases in which caseation is suspected, as the probable result would be a spread of the area destroyed by caseation. 